\title{
Empirical Analysis of Teacher's Accountability as an Instrument of Effective Policy Implementation in Nigeria
}

\author{
Ibrahim Yaro (Corresponding Author) \\ School of Government Universiti Utara Malaysia \\ Tel: +60-113-654-1040Ｅ-mail: yaro048@yahoo.com \\ Dr. Rozita Binti Arshad \\ School of Government Universiti Utara Malaysia \\ Tel: +60134899696Ｅ-mail: roz@uum.edu.my \\ Associate Professor Dr. Dani Bin Salleh \\ School of Government Universiti Utara Malaysia \\ Tel: +60-135-225-586Ｅ-mail: dani@uum.edu.my
}

Doi:10.5296/ jpag.v5i4.8603 URL: http://dx.doi.org/10.5296/ jpag.v5i4. 8603

\begin{abstract}
Accountability in discharging official duties is very essential as it increases effectiveness and efficiency in service delivery. As public servants teachers are expected to demonstrate high level commitment in the teaching and learning process as this will lead to the attainment of quality education. The paper pointed out that where secondary education is of good quality, right students will be admitted into tertiary institutions of learning and subsequently, competent graduates will be produced who will work in different capacities. Literate workforce is however capable of implementing government's policies in a more effective and efficient manner. The research employs descriptive research analysis to analyze teacher's accountability in secondary schools of Sokoto state, Nigeria. The results showed pleasing teacher's accountability. The paper therefore recommends that the government should intensify efforts and put in place more appropriate mechanisms including motivation and constant training and re-training of the teachers in order to maintain the tempo as this will ensure the attainment of the much needed quality education and subsequently effective implementation of government policies.
\end{abstract}

Keywords: Accountability, Policy Implementation, Quality Education, Secondary School Teachers 


\section{Introduction}

Governments the world over are continuously craving for effectiveness in organizations through accountability. Being part of the principles of good governance, accountability refers to the obligation on the part of government and its officials to discharge their duties accordingly in line with the stipulated rules (Adegite, 2010). This is indispensable as governments are constantly initiating policies and programs for the benefit of the masses. These policies are most often implemented by the public servants or the bureaucrats who are entrusted with the power to accomplish the mission of making essential services available to the general public on behalf of the government as such the bureaucrats are expected to be accountable to the government (Onuorah and Appah, 2012) otherwise the overall aims will be defeated.

However, government efforts in striving to ensure accountability in service delivery necessitated the need to employ people with proven integrity; those with the requisite knowledge, zeal and enthusiasm to demonstrate commitment to perform on the job (Newell $\&$ Shackle ton 2000) towards the accomplishment of the goals, aims and objectives set forth by the government. This applies to all sectors of the economy education sector inclusive. In Nigeria for example, there have been pervasive degradation of the public sector due to corruption that affects almost everyone either as a doer or as a victim (Iyanda, 2012) as a result of lack of accountability. The employees are most often found wanting in discharging their responsibilities and the government does not put in place adequate control mechanisms to check-mate their actions. This is one of the grave challenges and the reasons why the Nigerian education sector has not been able to over the years deliver.

This paper is aimed at analyzing teacher's accountability in secondary schools Sokoto state. The reason for focusing on secondary schools teachers is based on the fact that teachers are the disseminators of knowledge and that secondary education lays the foundation of future useful members in the society because it is at this level of study that students with diverse talents and abilities are identified (Caillods, F. 2010) and this gives room for empowering them towards harnessing their potentials in its fullest form.

Furthermore, the less attention given to the secondary education sector (UNESCO, 1999) led to producing incompetent secondary school leavers that end-up in tertiary institutions of learning with nothing to contribute to the society after completion of studies. This is the case in most developing countries Nigeria inclusive. In Nigeria for example and to be precise in the North West of which Sokoto state is part of, this exactly the problem confronting the zone. The argument here is that where teachers are accountable and demonstrate high level of commitment in discharging their duties, effective teaching will take place and when there is effective teaching, quality education will be obtained. Teachers' accountability is thus a pre-requisite to the attainment of quality education and that the recipients of quality education at secondary school level, are believed to excel in tertiary institutions of learning. These are the type of people who will work in various government institutions upon graduation. It is also a well-known fact that highly literate workforce is capable of implementing any government policy or program in a more professional and effective manner and as such a 
development that is sustainable will be ensured.

Recently the United Nations (UN) comes up with new Sustainable Development Goals of the year 2015 tagged "Transforming our world-the 2030 agenda for Sustainable Development". Item number four (4) of the seventeen (17) goals stated thus: "Ensure inclusive and equitable quality education and promote life-long learning opportunities for all". This is paramount as Bunyi (2013) stated: "it is not education alone that matters but quality education because when education is of good quality, students tend not to drop out of the education system and that individuals who have stayed in school for a long period of time are believed to have higher working life earnings compared to those who drop out early". This will also enable the students to develop and imbibe good characters that will enable them become good citizens and the opportunity of becoming future leaders.

The paper will begin with a review of literature and research methodology. The paper will then discuss the results of the analysis, offer recommendations and finally conclusion.

\section{Literature Review}

\subsection{Accountability}

Accountability in public service is fundamental for successful governance in organizations being it a mechanism of ensuring that effective services are offered to the public by the government (Agara, 2009). Accountability denotes the superiority of government intentions and policies over the personal feelings of the of the policy implementers who are expected to discharge their duties according to the stipulated rules. This in essence means that while discharging official duties sentiments, personal and other primordial issues should be set aside. The public servants should be neutral even if they have their own perception of how issues are supposed to be tackled.

The word Accountability is sometimes used to mean "responsibility" which is often translated as the type of connection between an employer and an employee based on an agreement to perform duties and responsibilities (Odunayo, 2014). Accountability according to Onuarah and Appah (2012) "is about being answerable to those who have invested their trust, faith and resources to you". The public servants are therefore, expected to report their actions to their superiors based on the agreed framework of discharging and answerability to duty. This is also the view of Adegite (2010) who posits that accountability is "the obligation to demonstrate that work has been conducted in accordance with the agreed rules and standards and the officer reports fairly and accurately on performance results vis-à-vis mandated roles or plans". Conformity to the laid down rules and regulations while discharging official duties is therefore very essential while at the same time utmost care should be taken to perform it in a more transparent and effective manner.

Okoh and Ohwoyibo, (2009) posits that "accountability reflects the needs for the government and its agencies to serve the public effectively in accordance with the laws of the land". The norms and code of ethics are the guiding principles of discharging official duties in both public and private organizations and as such they are expected to be adhered to strictly especially during policy decisions making. However, the world development report in World 
Bank (2003) reported that accountability is a central agent of organizational change in service delivery due to its paramount importance. It used in government institutions as a control mechanism and a tool of regulating the behaviors of employees (Eckardt, 2008). The fundamental concern of accountability in public institutions is to see that the day to day activities of the government are being discharged sincerely so that the general public will all benefit from it (Lanre and Tomola, 2010). Odunayo (2014) asserted that in leadership roles, accountability "is the acknowledgement and assumption of responsibility of actions within the scope of role in position encompassing the obligation to report and be answerable for resulting consequences". Odunayo further stated that "accountability is a liability assume by all those who exercise authority to account for the manner in which they have fulfilled responsibilities entrusted in them". By being accountable the employees will appreciate the value of goal attainment in accordance with the planned standard criteria (Odunayo, 2014). Accountability therefore requires an account of the actions taken by the employees to be given (Dennis Osborn, 2004).

Educational accountability is an attempt of ensuring that education stakeholders especially the teachers act responsively in discharging their duties in order to enhance educational quality (Bandele, 2007). Bandele further noted that secondary school's education stakeholders are many and each and every one of them is expected to contribute towards the realization of the objectives which in Nigeria are designed to produce capable graduates who will be useful not only to themselves but to the country at large. Accountability in a school system is the obligation on the part of the teachers to impart the right type of knowledge to students in an effective manner. Also accountability is more than obeying the laid down rules, it is currently seen as results oriented as the attention of good governance is more on outputs than on inputs. That is why accountability in the teaching profession is required so that the goals of attaining quality education in schools which is the expected education output will be achieved. Teachers who are the focus of this study and part of education stakeholders (Halle, Mokeki \& Marinda 2011) ; drivers of academic activities and agents of student's achievements (Branford et al, 2005; Sacilotto-Vasylenko, 2013) should therefore, act responsively (Odunayo, 2014) and teach effectively (Adegite, 2010) in line with the stipulated rules (Ohwoyibo, 2009) so that the overall aim will not be defeated. This will ensure the attainment of not only quality education but subsequent implementation of government policies and programs.

\subsection{Policy Implementation}

Implementation is all about execution of government policies (Kraft \& Furlong, 2007; Ajaegby \& Eze, 2010). Paudel (2009) sees implementation as undertaking a task to achieve some targeted goals. It encompasses all the procedure and efforts of actualizing the policies decided upon by the government in order to attain the desired outcome as prescribed in the policy guidelines. In other words policy implementation is the routine administrative procedures of purring the targeted goals set by the government into action which is normally carried out by the government agencies or its officials in line with the stipulated laws. Effective implementation in the secondary education sector is therefore, required as this will subsequently lead to the realization of the targeted outcome i.e. the attainment of quality 
education.

\section{Research Methodology}

The research used a descriptive research technique using a six point Likert scale questionnaire. The questionnaire was administered to a sample of forty (40) respondents one in each of the forty three (43) secondary schools within the Sokoto metropolis out of which the response of thirty three (33) participants was obtained. From the responses obtained however, thirty (30) are fit for analysis. Therefore, the research is based on a sample of thirty (30) respondents.

\section{Results and Discussion}

Table 1: Mean and Standard Deviation

\begin{tabular}{|l|l|l|l|l|}
\hline S/N & Minimum & Maximum & Mean & $\begin{array}{l}\text { Std. } \\
\text { Deviation }\end{array}$ \\
\hline 1. & 1 & 6 & 4.47 & 1.592 \\
\hline 2. & 1 & 6 & 4.90 & 1.447 \\
\hline 3. & 1 & 6 & 4.93 & 1.484 \\
\hline 4. & 1 & 6 & 4.87 & 1.306 \\
\hline 5. & 1 & 6 & 4.87 & 1.358 \\
\hline 6. & 1 & 6 & 4.80 & 1.627 \\
\hline 7. & 2 & 6 & 5.03 & 1.217 \\
\hline 8. & 2 & 6 & 5.10 & 1.125 \\
\hline 9. & 1 & 6 & 5.13 & 1.332 \\
\hline 10. & 2 & 6 & 4.97 & 1.217 \\
\hline 11. & 2 & 6 & 4.57 & 1.040 \\
\hline 12. & 1 & 6 & 4.60 & 1.163 \\
\hline 13. & 1 & 6.43 & \\
\hline
\end{tabular}


From the above table, it was observed that question one which stated that "Teachers should be sensitive to exploit educational opportunities for their students" has a mean of 4.47 with a corresponding standard deviation of 1.592. In the second question which stated that "Teachers should strengthen students in their areas of weakness" have a mean of 4.90 and a standard deviation of 1.447. Question three stated that: "Teachers should always relate the instructional objectives to broad educational objectives" and have a mean of 4.93 and a standard deviation of 1.484. The fourth question stated that "Extra-curricular activities should be designed towards student's development" it has a mean of 4.87 and a standard deviation of 1.306. On the fifth question which stated that "Teachers should encourage regular visit to school by parents for the inspection of their children's academic activities" the mean observed is 4.87 and a standard deviation of 1.358. The sixth question stated that "Teachers should encourage parents to buy essential books and relevant materials needed by their children from time to time" the mean observed is 4.80 with a standard deviation of 1.627. "Teachers should encourage objective assessments of their students from time to time" is the seventh question and has a mean of 5.03 and a standard deviation of 1.217. The eighth question stated that "Teachers should teach moral education into their students" the question record a mean of 5.10 and a standard deviation of 1.125 . However, a mean of 5.13 with a corresponding standard deviation of 1.332 was observed in question nine which stated that "Teachers should encourage students to be hard working in their studies". The $10^{\text {th }}$ question stated that "Teachers should encourage students to maintain school and personal cleanliness" the question has a mean of 4.97 and a standard deviation of 1.217. Eleventh question has a mean of 4.57 and a standard deviation of 1.040. The question stated that "Teachers should encourage students in the leadership and democratic roles". Question twelve stated that "Teachers should take cases of student's problems to schools counselors promptly" a mean of 4.60 with a standard deviation of 1.163 was observed. The last question i.e. question thirteen stated that "Teachers should reside near their schools as living in distant places can affect their getting to school on time." a mean of 4.43 and a standard deviation of 1.406 was observed.

From the results obtained, it was discovered that all the questions have a mean above 4.50 i.e. between "Agree" to "Strongly agree". The highest mean score of 5.10 and 5.13 is obtained in question eight (8) \& question nine (9) respectively.

Question eight stated that "Teachers should teach moral education to their students." This is indeed a good move in the right direction for the fact that inculcating moral attitudes is one of the bases of quality education. Sifuna (2009) observed that quality education is associated with improvements in the cognitive achievement of students and improvements in the social and economic lives of their societies. Such individuals tend to develop character traits such as perseverance, honesty, determination and reliability that are encouraged in schools and that are required and rewarded in the job market. Therefore morality of students is beneficial not only to themselves but to the entire nation as it leads to honesty, sincerity, hospitability and effectiveness in discharging responsibility. 


\section{Macrothink}

Question nine on the other hand states that "Teachers should encourage students to be hard working in their studies." This is very imperative in as much as acquiring quality education is the goal which is the final outcome of secondary education. David \& Don, (2002) \& Sifuna, (2009) opined that "Quality education involves four issues namely: inputs, process, output and outcomes. The input includes the number of teachers available, the amount of teacher training as well as the number of textbooks. The process involves the amount of direct instructional materials and the extent of active learning. The output includes test scores and graduation rates while the outcome includes performance in subsequent employment". Whatever materials are put place and however effective the teachers teaches in class once the students are not hardworking the end results may not be achieved. There is therefore the need for trained, qualified and committed teachers who are always willing to perform their duties with zeal and enthusiasm (Chong, 2013); those teachers who always act as role model to the students and encourages them to be steadfast and stand on their own. Such teachers are the facilitators and drivers of student's success and achievements (Branford et al, 2005; Sacilotto-Vasylenko, 2013).

However, almost all the questions centered on how teachers can induce the right habit and excellent academic attitude to the students and by so doing the students are being groomed for a better future. Teacher's accountability is thus regarded as a vital ingredient in societal transformation and development.

Table 2: Questionnaire Scale Administered showing frequency and percentage

\begin{tabular}{|c|c|c|c|c|c|c|}
\hline Question & $\begin{array}{c}\text { Strongly } \\
\text { Disagree }\end{array}$ & Disagree & $\begin{array}{c}\text { Slightly } \\
\text { Disagree }\end{array}$ & $\begin{array}{c}\text { Slightly } \\
\text { Agree }\end{array}$ & Agree & $\begin{array}{c}\text { Strongly } \\
\text { agree }\end{array}$ \\
\hline 1 & 3 & 0 & 6 & 1 & 11 & 9 \\
\hline 2 & 1 & 1 & 5 & 1 & 7 & 15 \\
\hline 3 & 2 & 0 & 3 & 4 & 5 & 16 \\
\hline 4 & 1 & 0 & 5 & 4 & 6 & 14 \\
\hline 5 & 2 & 2 & 3 & 1 & 7 & 15 \\
\hline 6 & 2 & 0 & 3 & 0 & 12 & 13 \\
\hline 7 & 0 & 1 & 3 & 2 & 10 & 14 \\
\hline 8 & 1 & 1 & 3 & 2 & 12 & 11 \\
\hline 9 & 1 & 1 & 2 & 2 & 7 & 17 \\
\hline 10 & 0 & 1 & 5 & 1 & 10 & 13 \\
\hline 11 & 0 & 1 & 4 & 7 & 13 & 5 \\
\hline 12 & 1 & 1 & 2 & 6 & 15 & 5 \\
\hline 13 & 1 & 2 & 5 & 5 & 9 & 8 \\
\hline Total Freq. & 15 & 11 & 49 & 36 & 124 & 155 \\
\hline Percentage & $3.85 \%$ & $2.82 \%$ & $12.56 \%$ & $9.23 \%$ & $31.79 \%$ & $39.74 \%$ \\
\hline
\end{tabular}

Furthermore, the table above shows the questionnaire scale administered which indicated that a total of $3.87 \%$ of the respondents with a frequency of fifteen (15) answered "Strongly Disagree" in all the questions administered. $2.87 \%$ of the respondents with a frequency of eleven (11) answered "Disagree" in all the questions administered. $12.56 \%$ of the respondents 
with a frequency of forty nine (49) answered "Slightly Disagree" in all the questions administered. Also $9.23 \%$ of the respondents with a frequency of thirty six (36) answered "Slightly Agree" in all the questions administered. $31.79 \%$ of the respondents with a frequency of one hundred and twenty four (124) answered "Agree" in all the questions administered. 39.74\% of the respondents with a frequency of one hundred and fifty five (155) answered "Strongly Agree" in all the questions administered.

This indicates that majority of the respondents supported teachers accountability for the fact that accountability in the teaching profession is very vital and it goes beyond acting according to the stipulation of the law; nowadays accountability is considered as results oriented being that good government plays more emphasis on the final results i.e. the output which in secondary schools is the attainment of quality education. Teachers are therefore expected and supposed to be accountable in discharging their responsibilities so that the aim of ensuring quality education can be achieved.

\section{Conclusion}

Accountability in the public service is a sort of control mechanism and a means of checking the excesses of the public servants. It is useful in the sense that it leads to effectiveness and efficiency in service delivery. Accountability is also seen to be a means of implementing government policies and programs effectively. In the education sector, teacher's accountability is bound to lead to attaining quality education. Also the foundation laid at secondary school level for quality education leads to admitting competent students into tertiary institutions that are believed to excel in their studies and work in different government institutions upon graduation. It is also a well-known fact that highly literate workforce is capable of implementing government policies and programs in a professional, competent, effective and efficient manner. Teacher's accountability is therefore seen as a vital instrument of ensuring quality education and also a means of effective service delivery and effective policy implementation in public institutions.

The research thus recommends that the government should put in place more efforts in order to ensure that teachers are adequately motivated so as to give in their best. Positive motivation boosts teacher's morale towards achieving greater output. The government should therefore intensify efforts to train and re-train the teachers, provide all the necessary facilities and other materials required for effective teaching and learning to take place in schools. This is believed to make the teachers more accountable and sit up to their responsibilities.

\section{References}

Adegite, E. O. (2010). Accounting Accountability and National Development. Nigerian accountant 43(1), 56-54

Agara, T. and Olarinmowe, O. (2009). Ethics and accountability in Nigeria's Public Service: Historical Overview. Journal of Public Administration and Policy Research. 1(1), 11-18

Ajaegbe, F.O. \& Eze, E. (2010). Public Policy Making and Analysis. Enugu: Spring Time Press. 
Andrei, O. P., Nicoleta, B. and Andrian, F. (2013). Quality Based Education and the Stakeholders Expectations. Economy Trans-disciplinary Cognition, 16(1), 72-78

Bunyi, G. W. (2013). The quest for quality education: the case of curriculum innovations in Kenya. European Journal of Training and Development, 37(7), 678-691.

Brans ford, J. D. L. and Le Page, P. (2005), "Introduction", in Darling-Hammond, L. and brans ford, J. (Eds), Preparing Teachers for a Changing World: What Teachers Should Learn and be Able to Do, Jossey-Bass, San Francisco, CA, pp. 1-39.

Caillods, F. (2010). Access to Secondary Education. Asia pacific: Secondary Education System Review Series.

Chong, S. (2014). Academic quality management in teacher education: a Singapore perspective. Quality Assurance in Education, vol. 22(1), 53-64.

David, C., and Don, A. (2002). Quality of Education: Dimensions and Strategies. Education in Developing Asia vol. 5

Dennis, O. (2004). Transparency and Accountability reconsidered. Journal of Financial crime 11(3) 292-300

Helle, D. L. M., and Marinda, W., (2011). Perception of knowledge of rules and respect among educators: teachers as an indicator of integrity. (Online) available: www.un.org/tisda

Iyanda, D. O. (2012). Corruption: Definitions, Theories and Concepts. Arabian Journal of Business and Management Review 2(4), 37-45.

Kraft, M. \& Furlong, S. (2007). Public Policy: Politics and Analysis. Washington: CQ Press.

Lanre, O. A., (2010). Public accountability: implications of the conspirational relationship between political appointees and civil servants in Nigeria. International Business, 2, 123-127

Newell, S. S. V., (2000). Selection and assessment as an interactive decision-action process. London: FT/Prentice Hall

Odunayo, H. A., (2014). Internal Control System: A managerial tool for proper accountability a case of Nigeria custom service. European Scientific Journal, 10(13)

Okoh, L. and Ohwoyibo, O. (2010). Public accountability: vehicle for socio-economic development of Nigeria. International Journal of investment and finance, 3(1 \& 2), 145-149

Paudel, N. R. (2009). A Critical Account of Policy Implementation Theories: Status and Reconsideration. Nepalese Journal of Public Policy and Governance, 25(2), 36-54.

S. Eckardt, (2008). Political accountability, fiscal conditions and local government performance: Cross-sectional evidence from Indonesia. Public Administration Development, 28(1), $1-17$

Sifuna, D.N. (2009), "Concept and function of quality education", paper presented at the Japan Education Forum vi, National Center of Science Building, Chiyoda-ka/Tokyo, 6 
February.

Sacilotto, V. M., (2013). Bologna process and initial teacher education reform in France. International Perspectives on Education and Society, 19, 3-24.

United Nations Educational, Scientific and Cultural Organization (1999). Education Sector Analysis.

(Online) available: http://www.unesco.org/education/educprog/erd/english/com/news/workshop_alb.html

Onuorah, A. C., and Appah, E. (2012). Accountability in the public sector financial management in Nigeria. Arabian Journal of Business and Management Review. 1(6),

World Bank Development Report, (2003). Making service work for the people. The world Bank and Oxford University press, Washington DC. 